\title{
Laporan Keuangan Perspektif SIRI
}

\author{
Chairul Iksan Burhanuddin ${ }^{1}$, Fifi Nur Afifah Ibrahim², Burhanuddin ${ }^{3}$ \\ Universitas Muhammadiyah Makassar, Universitas Muslim Indonesia, Universitas \\ Negeri Makassar \\ chairul.iksan@unismuh.ac.id, fifinurafifah.ibrahim@umi.ac.id, \\ burhanuddin@unm.ac.id
}

*Penulis Korespondensi

Diajukan : 1 Desember 2021

Disetujui : 6 Desember 2021

Dipublikasi : 01 Januari 2022

\begin{abstract}
In order to provide information and make choices, financial reports are delivered to relevant parties. However, because there are so many parties interested in the financial accounts, there is a lot of information asymmetry in the process of presenting them. In order for the information to be used as a firm foundation for internal and external parties, a new perspective is required in the process of presenting financial statements. In order to interpret the meaning of the SIRI perspective financial statements, this study used a qualitative method that was supplemented by a literature review. So that a conclusion regarding the presentation of fresh financial statements can be formed. The findings of this study offer a framework for presenting financial statements from four different perspectives: spiritual Integrity, Reso', and ininnawa. With the goal that these four viewpoints will influence the way financial statements are presented. And, in the future, bring benefits to both internal and external parties.
\end{abstract}

Keywords: Financial Report, Spiritual, Integrity, Reso', Ininnawa

\section{PENDAHULUAN}

Penyajian laporan keuangan oleh setiap organisasi merupakan bentuk pelaporan dan pertanggungjawaban perusahaan terhadap stakeholder atau pihak yang berkepentingan sebagai bentuk informasi dan komunikasi mengenai hasil kegiatan operasional perusahaan selama periode tertentu. (Wantah, 2015) mengemukakan bahwa laporan keuangan merupakan pengungkapan terstruktur dari situasi keuangan dan kinerja keuangan suatu entitas, yang diukur dalam nilai moneter. Neraca, laporan laba rugi, laporan perubahan ekuitas, laporan arus kas, dan catatan atas laporan keuangan membentuk laporan keuangan yang lengkap. Selain itu, tujuan laporan keuangan adalah untuk menyediakan pengguna laporan dengan informasi tentang situasi keuangan entitas, kinerja keuangan, dan arus kas yang akan membantu mereka dalam membuat keputusan ekonomi. Isu penyajian laporan keuangan dinyatakan (Nei et al., 2018) sebagai sesuatu yang sangat perlu diperhatikan karena sangat berkaitan dengan proses pengambilan keputusan. Hal ini sejalan dengan penelitian yang dilakukan (Alam et al., 2018) dan (Boisjoly, 2017) mengenai peran penting seorang akuntan dalam proses penyajian laporan keuangan yang berbobot. Sehingga informasi yang disajikan tidak menimbulkan multipersepsi atau kesenjangan informasi. Sehingga diperlukan suatu paradigma baru dalam proses penyajian laporan keuangan yang efektif. 
(FASB, 1980) menyatakan integritas laporan keuangan merupakan suatu informasi dalam laporan keuangan yang disajikan secara wajar, tidak bias dan jujur dalam menyajikan informasi. (Mayangsari, 2003) mengemukakan bahwa integritas laporan keuangan adalah sejauh mana laporan keuangan yang disajikan menunjukkan informasi yang benar dan jujur, integritas informasi laporan keuangan tidak hanya dilihat dari sisi besarnya kualitas laba saja, karena laba akrual masih dipengaruhi oleh kebijakan dan metode akuntansi yang digunakan. Untuk mengukur integritas laporan keuangan secara intuitif dapat diukur dengan konservatisme dan manajemen laba. Seiring adanya perubahan standar akuntansi keuangan dari GAAP (Generally Accepted Accounting Principles) ke IFRS (International Financial Reporting Standards) maka prinsip konservatisme sudah mulai ditinggalkan dan diganti dengan menggunakan manajemen laba.

Manajemen laba merupakan suatu intervensi dengan maksud tertentu terhadap proses penyusunan laporan keuangan ekternal dengan tujuan untuk memaksimalkan keuntungan pribadi dengan cara memilih metode dan kebijakan akuntansi tertentu untuk menaikkan atau menurunkan laba (Schipper, 1989). Apabila laporan keuangan yang dibuat manajemen mengandung banyak manajemen laba maka bisa dikatakan laporan keuangan itu tidak berintegritas. Realita yang terjadi saat ini beberapa perusahaan mengelola laporan keuangan dengan penyajian nominal angka yang dibuat sedemikian rupa untuk kepentingan tertentu. Jika perusahaan berkepentingan dengan investor, maka keuntungan yang dicantumkan di Laporan Laba Rugi dinaikkan, begitu juga sebaliknya dalam urusan membayar pajak maka laba diturunkan. Kondisi seperti ini yang dianggap wajar sebagai praktik manipulasi data yang sebenarnya dapat berdampak buruk khususnya bagi investor, kreditor, supplier maupun stakeholder.

Banyak pertimbangan perspektif yang dapat dijadikan acuan dalam penyajian laporan keuangan. Misalnya dalam perspektif spiritual, Nilai-nilai yang dianut dari praktik manajemen laba idealnya tidak sesuai dan tidak mengandalkan etika khususnya jika ditinjau dari sisi spiritualisme, sehingga tidak terciptanya integritas dalam menciptakan rasa keadilan dalam penyajian laporan keuangan khususnya bagi semua pengguna laporannya. Fenomena spiritualitas merujuk pada kesadaran pelaku bisnis bahwa keuntungan yang diperoleh tidaklah sebatas nominal profit jangka pendek di dunia, namun juga tercapainya profit jangka panjang di akhirat. Kata Latin "spiritus", juga berarti "roh, jiwa, sukma, kesadaran diri, wujud tak berbadan, nafas hidup, dan nyawa hidup". Dalam Kamus Besar Bahasa Indonesia, kata spiritual berarti berhubungan dengan atau bersifat kejiwaan (rohani, batin).

Perspektif lainnya yaitu dalam perspektif budaya, khususnya budaya masyarakat bugis. Suku Bugis merupakan salah satu suku tertua di Indonesia. Suku ini mendiami sebagian besar daratan Sulawesi Selatan. Masyarakat Bugis diakui menganut sejumlah prinsip dan nilai yang didukung masyarakat dalam kehidupan sehari-hari. Menurut buku 'Mengungkap Nilai Kearifan Lokal Bugis Makassar: Perspektif Hukum dan Pemerintahan, budaya Bugis Makassar kaya akan agama, kearifan, etika dan estetika, perasaan dan kejujuran yang dirancang untuk Tuhan. Beberapa nilai-nilai budaya yang begitu kuat dipegang teguh oleh masyarakat bugis diantaranya Reso' dan Ininnawa. 
Reso' berarti ketekunan dan kerja keras, hidup sering dimaknai oleh orang Bugis sebagai banyak berusaha keras (Reso). Semakin cepat suatu teori dapat dipahami dari sudut pandang bisnis/pekerjaan, semakin baik. Arti dari Reso adalah sistem dengan nilai kehormatan, yang merupakan salah satu wujud dari cita-cita siri, bahkan di antara adatistiadat orang Bugis. Orang Bugis malu jika seseorang yang cukup umur tetapi menganggur menjadi beban bagi orang lain (masiri narekko tuo mappale), maka tidak heran jika suku Bugis menganut prinsip Reso' temmangingngi nalletei pammase dewata (usaha atau benar-benar dibarengi dengan ridho Yang Maha Kuasa), hal inilah yang menjadikan suku Bugis sangat terkenal mengenai pendiriannya.

Inninawa dalam kata Bugis yang berarti "melakukan apa yang diperintahkan hati". Kata ininnawa berasal dari kata nawa dan nawa-nawa. Nawa-nawa mengacu pada sesuatu yang masih dalam pertimbangan. Apakah nawa-nawa itu baik atau buruk, nawanawa digolongkan sebagai nawa-nawa untuk memberikan konotasi luas yang bisa positif dan negatif. Jika nawa-nawa itu baik, maka disebut sebagai Ininnawa. Akibatnya, Ininnawa adalah produk dari proses kognitif yang didasarkan pada harmoni akal dan hati nurani, dengan tujuan mulia untuk mencapai harapan sejati sebelum bertindak. Ininnawa adalah konsekuensi dari hati atau hati nurani yang murni, bersih tanpa niat jahat yang melalui proses perenungan.

Jika setiap perusahaan mengandalkan nilai - nilai tersebut yaitu nilai spiritual atau agama, Reso' atau ketekunan dan kerja keras, serta inninawa atau mengerjakan sesuatu sesuai dengan kata hati tentu hal ini bisa menjadi pertimbangan dalam proses penyajian laporan keuangan yang akuntabel dan dapat dipertanggungjawabkan.

Dengan adanya berbagai isu penyajian laporan yang telah dikemukakan, maka penelitian ini akan berfokus pada solusi-solusi yang akan memberikan penyelesaian masalah yang berkaitan dengan penyajian laporan keuangan dengan menyandarkan solusinya pada perspektif baru. Oleh karena itu tema penelitian yang akan diteliti mengenai Laporan Keuangan Perspektif SIRI (Spiritual, Integrity, Reso, dan Ininnawa).

\section{Penelitian Terdahulu}

\section{STUDI LITERATUR}

Beberapa literatur mengungkapkan bahwa seharusnya penyajian laporan keuangan patut memiliki kegunaan dalam penyajiannya. Salah satunya adalah laporan keuangan dapat dipergunakan dalam pengambilan keputusan pada level puncak organisasi (Beuselinck \& Manigart, 2007). Hal ini sejalan dengan pendapat yang dikemukakan oleh (Jonas \& Blanchet, 2000) mengenai kualitas penyajian laporan keuangan dan pemanfaatannya. Begitu pula pendapat yang dikemukakan oleh (McDaniel et al., 2002) tentang penyajian laporan keuangan.

Beberapa metode penyajian laporan keuangan dapat digunakan sesuai dengan kebutuhan perusahaan. Misalnya metode akrual, Model metode akrual digunakan untuk mengukur sejauh mana manajemen laba sesuai dengan aturan secara umum dan perundang-undangan yang berlaku. Metode ini mengasumsikan bahwa manajer menggunakan akrual diskresioner, yaitu akrual di mana manajer dapat menggunakan beberapa kontrol, untuk mengelola dan melaporkan pendapatannya (revenue) (Healy \& 
Wahlen, 1999). Hal ini sejalan dengan apa yang dikemukakan oleh (P. M. Dechow et al., 1995) tentang praktik manajemen laba.

Akan tetapi, manajemen laba diasumsikan berpengaruh negatif terhadap kualitas pelaporan keuangan dengan mengurangi kegunaan keputusannya dimana hal ini dikemukakan oleh (Brown, 2014) dan (Van Tendeloo \& Vanstraelen, 2005). Namun terdapat keuntungan jika menggunakan akrual diskresioner untuk mengukur manajemen laba adalah dapat dihitung berdasarkan informasi dalam laporan tahunan. Selain itu, ketika menggunakan model regresi dimungkinkan untuk menguji pengaruh karakteristik perusahaan terhadap tingkat manajemen laba. Selain itu, ini hanya merupakan proksi tidak langsung dari kualitas laba, tidak termasuk informasi non-keuangan. Oleh karena itu, kesimpulan mengenai kualitas informasi pelaporan keuangan berdasarkan model akrual tidak memberikan bukti langsung dan komprehensif mengenai kualitas informasi pelaporan keuangan dan dimensi kegunaan keputusannya.

Informasi laba merupakan bagian penting dari keseluruhan pelaporan keuangan, penelitian sebelumnya sering menggunakan kualitas laba sebagai proksi untuk kualitas pelaporan keuangan. (P. Dechow et al., 2010) mengemukakan bahwa laba kualitas informasi laba yang lebih baik memberikan lebih banyak informasi tentang fitur kinerja keuangan perusahaan yang relevan dengan keputusan spesifik yang dibuat oleh pembuat keputusan tertentu, serta keputusan dari manajemen, menghindari distorsi pengungkapan, juga kesalahan estimasi, dan manipulasi ukuran laporan keuangan yang dilaporkan. Konsisten dengan hal ini, penelitian sebelumnya menunjukkan bukti empiris yang kuat tentang hubungan antara kualitas pelaporan keuangan dan praktik investasi. Misalnya, kualitas pelaporan keuangan secara positif terkait dengan efisiensi investasi untuk perusahaan publik besar pada negara Amerika Serikat serta perusahaan swasta dari pasar negara berkembang.

(Ramalingegowda et al., 2013) berpendapat bahwa di pasar yang tidak sempurna, kendala pendanaan eksternal yang berasal dari asimetri informasi dapat memaksa perusahaan untuk melupakan proyek investasi yang berharga untuk membayar dividen. Mereka menemukan bahwa pelaporan keuangan berkualitas tinggi secara signifikan mengurangi efek negatif dividen pada investasi, terutama pada investasi Research \& Development.

Selanjutnya, peran mitigasi kualitas pelaporan keuangan sangat penting di antara perusahaan dengan porsi nilai perusahaan yang lebih besar yang disebabkan oleh adanya pertumbuhan. Hasil penelitian mengemukakan peran penting kualitas pelaporan keuangan dalam mengurangi konflik antara keputusan investasi dan dividen perusahaan, sehingga mengurangi kemungkinan perusahaan melupakan proyek investasi yang berharga untuk membayar dividen. Hal ini dikemukakan oleh (Lo, 2015) yang melakukan penelitian tentang hubungan kredibilitas akuntansi dan kemampuan perusahaan untuk mendanai investasi mereka. Temuan menunjukkan bahwa bank yang telah diaudit memungkinkan dapat mengakses pendanaan dengan lebih baik selama periode pengetatan moneter daripada bank yang tidak diaudit.

Selain itu, beberapa penelitian lainnya mempertimbangkan dampak kualitas pelaporan keuangan dalam Krisis Keuangan Global tahun 2008 (Barth \& Landsman, 
2010). Lebih dari itu, (Lin et al., 2014) meneliti dampak kualitas pelaporan keuangan pada likuiditas di pasar ekuitas selama krisis keuangan global 2008-2009 di Inggris. Penelitian tersebut menemukan bahwa likuiditas pasar jauh lebih rendah selama krisis daripada sebelum krisis. Namun, perusahaan dengan pelaporan keuangan yang dikelola dengan baik mengalami lebih sedikit efek negatif sebagai akibat dari krisis keuangan.

Penelitian lainnya yang mengungkap kualitas pelaporan keuangan di beberapa negara. Misalnya, (Bhattacharya et al., 2003) menggunakan 58.653 sampel pengamatan pada perusahaan dalam beberapa tahun dari 34 negara yang mencakup tahun 1986 hingga 1998. Berdasarkan tiga proksi manajemen laba, penelitian yang mereka lakukan memberikan daftar peringkat kualitas laba yang serupa untuk negara yang menjadi sampel. Selain itu, (Leuz et al., 2003) mengadopsi variabel yang dihitung dari 70.955 pengamatan dalam beberapa tahun pada perusahaan dimana total 8.616 perusahaan nonkeuangan untuk tahun fiskal 1990 hingga 1999 di 31 negara. Mereka menggunakan empat variabel manajemen laba dan mendokumentasikan perbedaan sistematis dalam kualitas laba di seluruh negara yang menjadi sampel. Penelitian yang mereka lakukan mengemukakan bahwa orang dalam perusahaan (agent dan principal), dalam upaya untuk melindungi manfaat dari pihak swasta, menggunakan manajemen laba untuk menyembunyikan kinerja perusahaan dari pihak eksternal. Dengan demikian, manajemen laba diharapkan dapat mengurangi informasi kepada investor karena kurangnya informasi pada laporan keuangan membatasi kemampuan orang dalam untuk memperoleh manfaat kontrol pada entitas, yang dapat mengakibatkan kurangnya insentif (bonus) dalam menutupi kinerja perusahaan. Temuan mereka menunjukkan hubungan endogen antara tata kelola Perusahaan (yaitu, perlindungan investor) dan kualitas laba yang dilaporkan. Singkatnya, studi ini menggunakan variabel akuntansi saja dan sebagian besar mengabaikan dampak sistem audit pada kualitas keseluruhan pelaporan keuangan.

Beberapa penelitian yang diungkapkan diatas dapat dimaknai bahwa banyak updaya yang dilakukan oleh pihak perusahaan dalam menyembunyikan informasi detail terkait kondisi keuangan dalam laporan keuangan. Walaupun telah dilakukan proses audit dan juga kontrol dari pihak manajemen, ternyata masih banyak perusahaan yang melakukan praktik manajemen laba dalam mengontrol informasi laporan keuangan yang disajikan kepada pihak yang berkepentingan (pajak dan lainnya). Dibutuhkan suatu nilai (value) yang dapat memutus adanya asimetri informasi pada laporan keuangan. Sehingga laporan keuangan dapat disajikan secara utuh dan sesuai dengan kondisi sebenarnya. Misalnya nilai agama (spiritual), nilai budaya, dan nilai yang dibangun oleh pendiri dapat menjadi pondasi kuat dalam menjaga keutuhan perusahaan. Misalnya dalam Islam, hubungan antara prinsip-prinsip Islam dan gagasan akuntansi untuk lingkungan merupakan sesuatu dari penekanan baru dalam literatur. Studi tentang Islam dan akuntansi, cenderung mengabaikan dimensi substantif dari fokus lingkungan dan budaya (al-Qaradawi, 2005). Oleh karena itu, diperlukan suatu perspektif dalam proses panyajian laporan keuangan yang baik sehingga informasinya dapat dimaknai dengan baik dan dipahami oleh pihak yang berkepentingan pada laporan keuangan tersebut.

\section{METODE}

Metodologi penelitian ini adalah deskriptif kualitatif, yaitu menghadirkan kejadian-kejadian atau fakta-fakta yang berkaitan dengan fenomena yang ada pada judul penelitian. Selain itu penelitian ini melakukan ekspolarasi untuk mengindentifikasi 
informasi baru melalui kajian literatur dari penelitian terdahulu. Sehingga dapat mematangkan suatu konsep dalam penyajian laporan keuangan perspektif baru. Menurut (Sgier, 2012) penelitian kualitatif adalah pengumpulan data pada suatu latar alamiah, dengan menggunakan metode ilmiah dan dilakukan oleh orang atau peneliti yang tertarik secara alamiah. Sehingga penelitian kualitatif adalah penelitian yang bermaksud untuk memahami fenomena tentang apa yang dialami oleh subjek penelitian, misalnya perilaku, persepsi, motivasi, tidakan dan lain-lain secara holistik dan dengan cara deskripsi dalam bentuk kata-kata dan bahasa, pada suatu konteks khusus yang alamiah dan dengan memanfaatkan berbagai metode alamiah.

Usaha-usaha penelitian bertujuan untuk mengindetifikasi serta mengumpulkan tipe-tipe informasi baru dalam proses penelitian ini. Selain itu kecukupan referensi diperlukan untuk menginterpretasi literatur yang ditemukan untuk menemukan sebuah konsep baru dalam hasil penelitian.

Tabel 1. Pendekatan Penelitian Laporan Keuangan Perspektif SIRI'

\begin{tabular}{|c|l|l|}
\hline NO & \multicolumn{1}{|c|}{ PENDEKATAN } & \multicolumn{1}{c|}{ KUALITATIF } \\
\hline 1 & Metode & Grounded Theory \\
\hline 2 & Teknik Pengumpulan data & Kajian literatur - jurnal/penelitian terdahulu \\
\hline 3 & Instrumen pengumpulan data & Buku dan internet \\
\hline 4 & Analisis & Interpretasi hubungan antara konsep/teori dan lainnya \\
\hline 5 & Produk & Konsep/Teori \\
\hline
\end{tabular}

Sumber: (Bogdan \& Taylor, 1975).

\section{HASIL}

Pembayaran deviden yang tinggi menjadi ancaman bagi debtholders karena akan menggurangi aktiva yang seharusnya teredia untuk pelunasan utang. Untuk mengatasi masalah ini, tindakan yang dapat dilakukan adalah dengan cara melakukan pembatasan pembagian deviden berdasarkan perolehan laba perusahaan. Untuk itu dibutuhkan penyajian laba yang konservatif demi membatasi pembayaran deviden yang terlalu tinggi serta penyajian aktiva yang konservatif untuk memberikan gambaran kepada debtholders tentang ketersediaan aktiva untuk pembayaran hutang. Pilihan metode tersebut akan berpengaruh terhadap angka yang disajikan dalam laporan keuangan. Sehingga dapat dikatakan bahwa secara tidak langsung konsep konservatisme ini akan mempengaruhi hasil dari laporan keuangan tersebut. Untuk itu dibutuhkan pengawasan seperti pemeriksaan laporan keuangan serta pembatasan keputusan yang diambil manajemen sehingga terciptanya integritas yang tinggi. Nilai integritas tersebut dapat digambarkan sebagai berikut: 


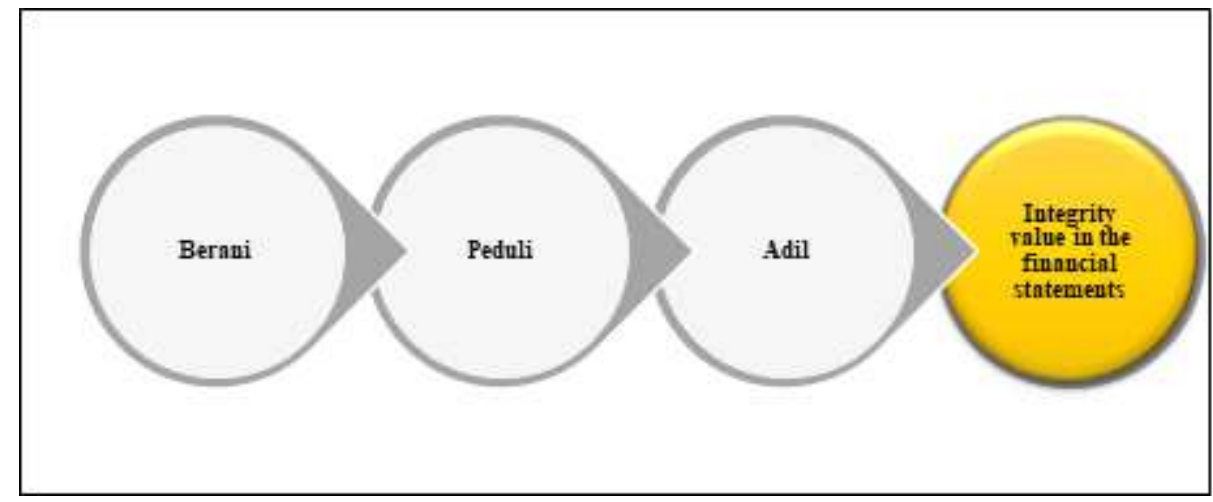

Gambar 1. Nilai Integritas dalam Penyajian Laporan Keuangan Sumber: Diolah sendiri

Selanjutnya religiusitas memiliki pengaruh terhadap perilaku seseorang di dalam dunia bisnis khususnya dalam penyajian laporan keuangan. Transparansi dalam penyajian laporan keuangan di sebuah organisasi sangat didukung oleh karakteristik personal para pelaksananya. Karakteristik personal yang didasarkan pada nilai-nilai religiusitas diantaranya sikap jujur, transparansi, dan mengutamakan kedisplinan sangat penting dalam meningkatkan outcomes organisasi. Semakin tinggi tingkat religiusitas seseorang maka akan meningkat pula motivasi dalam bekerja baik dari aspek kebutuhan akan prestasi, kebutuhan kekuasaan dan kebutuhan afiliasi. Bila seseorang karyawan memiliki kebutuhan akan prestasi dan afiliasi yang tinggi, maka akan semakin meningkatkan etos kerja dalam bentuk dedikasi terhadap pekerjaan, kreativitas kerja, nilai kerja dan kerjasama. Dari uraian argumentasi-argumentasi di atas, dapat disimpulkan bahwa komitmen religiusitas yang ada pada diri seseorang dapat menggiring seseorang kepada perilaku yang lebih etis, baik dalam lingkungan umum maupun secara khusus dalam lingkungan bisnis sehingga tercipranya transparansi dalam penyajian laporan keuangan (Mazereeuw-van der Duijn Schouten et al., 2014). Nilai Spiritual dapat digambarkan sebagai berikut:

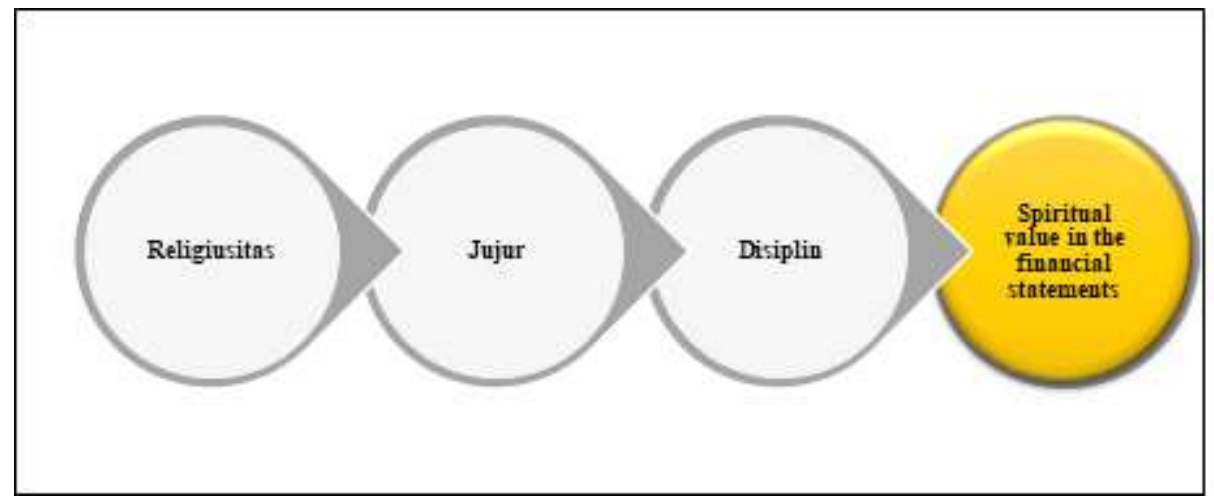

Gambar 2. Nilai Spiritual dalam Proses Penyajian Laporan Keuangan Sumber: Diolah sendiri

Nilai budaya Bugis lain yang disebut Reso (kerja keras atau usaha) dilihat dari beberapa ungkapan, serta pandangan pakar menyangkut hal ini. Reso dalam bahasa Bugis biasa dipadankan dengan kata kerja atau kerja keras (usaha) dalam bahasa Indonesia. Dalam kaitan dengan aktivitas manusia Bugis yang terkait dengan Reso sebagai 
manifestasi budaya dalam kehidupan manusia Bugis, sekaligus sebagai inti dari semua itu. Masyarakat Bugis memandang Reso sebagai simbol kehidupan, meniadakan Reso sama artinya dengan mengabaikan kehidupan itu sendiri. Masyarakat Bugis pada masa lampau dapat dipandang memiliki penghargaan yang tinggi terhadap waktu dalam kaitan dengan usaha atau kerja keras (Reso) (Nugraha, 2021).

Jika Reso dimaknai sebagai sesuatu yang disebut sebagai keteguhan, tepat guna, dan kerja keras maka hal ini dapat dimanfaatkan dalam proses penyajian laporan keuangan agar bentuk transparansi yang disajikan dapat dipertanggungjawabkan. Reso dalam penyajian laporan keuangan dapat digambarkan sebagai berikut:

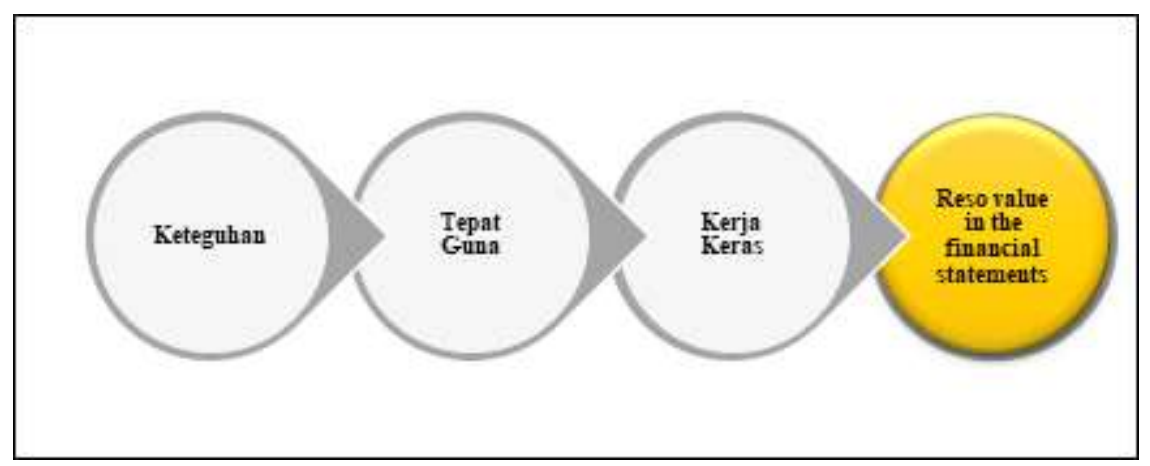

Gambar 3. Nilai Reso dalam proses penyajian laporan keuangan

Sumber: Diolah sendiri

Ketika isu transparansi masih banyak terjadi pada entitas, maka dibutuhkan suatu terobosan dan perspektif baru dalam penyajian laporan keuangan. Penelitian ini mengusulkan penyandingan budaya dan proses penyajian laporan keuangan. Dengan tujuan pelaporan keuangan yang disajikan tidak lagi multipersepsi atau disalahgunakan. Atau dengan kata lain penyajian laporan keuangan akan menjunjung tinggi nilai transparansi dalam implementasinya ketika disandingkan dengan nilai budaya. Nilai budaya yang dimaksud pada penelitian ini adalah ininnawa yang merupakan suatu nilai yang ada dalam budaya bugis. Unsur budaya bugis Ininnawa diusulkan agar proses penyajian laporan keuangan dapat disajikan dengan pertimbangan akal, hati nurani dan nilai luhur. Akal dimaknai sebagai daya pikir, ingatan yang hanya dimiliki oleh manusia, dapat pula dikatakan sebagai kecerdikan atau muslihat, sehingga akal biasanya dapat dimanfaatkan oleh manusia kearah yang baik maupun yang buruk (Tim Penyusun, 2008). Hati dan nurani memiliki keterkaitan sehingga disandingkan menjadi hati nurani yang dapat dimaknai sebagai sesuatu yang berkenaan dengan sifat atau hati seseorang, perasaan yang murni, dan lubuk hati yang paling dalam. Kemudian nilai luhur dimaknai sebagai sesuatu yang tinggi, mulia, sesuatu yang memberikan rasa hormat (Tim Penyusun, 2008). Sehingga dengan adanya unsur ininnawa dalam proses penyajian laporan keuangan akan memberikan rasa percaya diri kepada para penyaji laporan keuangan untuk betul-betul mempertimbangkan informasi yang terdapat didalam laporan keuangan sebelum disampaikan kepada pihak yang berkepentingan pada suatu entitas. Nilai ininnawa dapat digambarkan sebagai berikut: 


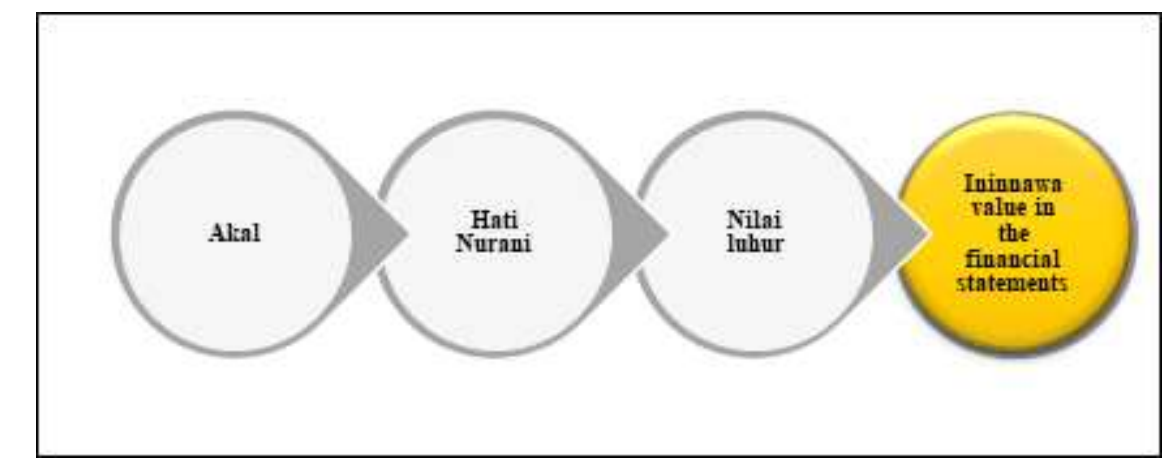

Gambar 4. Nilai Ininnawa Dalam Penyajian Laporan Keuangan

Sumber: Diolah sendiri.

\section{PEMBAHASAN}

Integritas secara terminologi berati mutu, sifat, atau keandalan yang menunjukkan kesatuan yang utuh sehingga memiliki potensi dan kemampuan yang memancarkan kewibawaan, kejujuran. Integritas laporan keuangan adalah sejauh mana laporan keuangan disajikan menunjukkan informasi yang benar dan jujur. Informasi akuntansi yang memiliki integritas yang tinggi dapat diandalkan karena merupakan suatu penyajian yang jujur sehingga memungkinkan pengguna informasi akuntansi bergantung pada informasi tersebut, sehingga memiliki kemampuan untuk mempengaruhi keputusan pengguna laporan keuangan. Laporan keuangan yang memiliki integritas tinggi harus memenuhi dua karakteristik utama dalam suatu laporan keuangan diantaranya kualitas primer, yaitu relevansi (relevance) yang merupakan kemampuan informasi untuk membantu pemakai dalam membedakan beberapa alternatif keputusan sehingga pemakai dapat dengan mudah menentukan pilihan dan keandalan (reliability) yaitu kemampuan informasi untuk memberikan keyakinan bahwa informasi tersebut benar atau valid (Weygandt et al., 2018).

Belum ada ukuran mengenai integritas laporan keuangan sampai saat ini. Meskipun demikian, secara intuitif dapat dipisahkan menjadi dua kategori yang diukur dengan konservatisme dan yang diukur dengan adanya manipulasi laporan keuangan, yang biasanya diukur dengan manajemen laba. Prinsip konservatisme dan penggunaan manajemen laba dapat digunakan untuk menilai laporan keuangan yang andal atau integritas karena informasi dalam laporan keuangan akan lebih andal jika laporan keuangan konservatif dan tidak melebih-lebihkan sehingga tidak ada pihak yang dirugikan oleh informasi tersebut di dalam laporan keuangan.

Konservatisme menurut (Barfuss \& Rosenberg, 1981) didefinisikan dengan reaksi hati hati (prudent reaction) dalam menghadapi ketidakpastian khususnya kehati-hatian dalam pelaporan keuangan di mana perusahaan tidak terburu-buru dalam mengakui dan mengukur aktiva dan laba serta mengakui kerugian dan hutang yang mempunyai kemungkinan akan terjadi. Penerapan prinsip ini mengakibatkan pilihan metode akuntansi yang ditunjukan pada metode yang melaporkan laba atau aktiva lebih rendah serta melaporkan hutang lebih tinggi Maksud utama lain meraka adalah untuk menetralisir optimisme para usahawan yang terlalu berlebihan dalam melaporkan hasil usahanya. 
Jika ditinjau lebih jauh ke dalam laporan keuangan, setiap metode akuntansi yang dipilih oleh perusahaan memiliki tingkat konservatisme yang berbeda-beda. PSAK tahun 2009, menyebutkan ada berbagai metode yang menerapkan prinsip konservatisme, diantaranya: (1) PSAK No.14 mengenai persediaan yang terkait dengan pemilihan perhitungan biaya persediaan, (2) PSAK No.16 mengenai aktiva tetap dan penyusutan, (3) PSAK No.19 mengenai aktiva tidak berwujud yang berkaitan dengan amortisasi dan (4) PSAK No.20 tentang biaya riset dan pengembangan.

Pilihan metode tersebut akan berpengaruh terhadap angka yang disajikan dalam laporan keuangan. Sehingga dapat dikatakan bahwa secara tidak langsung konsep konservatisme ini akan mempengaruhi hasil dari laporan keuangan tersebut. Penerapan konsep ini juga akan menghasilkan laba yang berfluktuatif, dimana laba yang berfluktuatif akan mengurangi daya prediksi laba untuk memprediksi aliran kas perusahaan pada masa yang akan datang (Sari \& Adhariani, 2009).

Terdapat pro dan kontra sehubungan dengan penerapan prinsip konservatisme. Pengkritik konsep konservatisme menyatakan bahwa prinsip ini mengakibatkan laporan keuangan menjadi bias sehingga dapat dijadikan sebagai alat untuk mengevaluasi resiko perusahaan. Semakin tinggi konservatisme, maka nilai buku yang dilaporkan semakin bias. Di lain pihak, terdapat pihak yang mendukung konsep konservatisme ini, diantaranya adalah (Haniati \& Fitriany, 2010) yang menyatakan bahwa konsep konservatisme dapat mengurangi konflik antara bondholders-shareholders seputar kebijakan deviden.

Lebih lanjut religiusitas berkaitan dengan semangat berketuhanan dan semangat beragama, jujur dalam konteks agama, disiplin dalam konteks agama Islam misalnya tepat waktu dalam beribadah. Religiusitas dikaitkan dengan tingkat pengetahuan seseorang, serta kekuatan keyakinan seseorang, jumlah ibadah dan hukum yang dipatuhi, dan kedalaman antusiasme seseorang terhadap agama yang dianutnya. Karena agama menjadi landasan bagi gagasan moral dalam diri individu, maka agama berdampak pada penciptaan sikap. Pemahaman dan pengetahuan tentang ajaran agama memberikan wawasan tentang baik dan buruk, serta garis pemisah antara apa yang boleh dan apa yang tidak boleh. (Nashori et al., 2002).

Menurut (Tikollah et al., 2006) keberagamaan (Religiusitas) dalam Islam bukan hanya terjadi ketika seseorang melakukan ibadah ritual saja, melainkan juga ketika melakukan aktivitas lainnya sehari-hari. (Mazereeuw-van der Duijn Schouten et al., 2014) menjelaskan lebih jauh bahwa orang yang memiliki motivasi religious internal memiliki pendirian yang lebih kuat ketimbang eksternal. Hal ini karena keyakinan internal yang selanjutnya menggiring kepada tindakan tertentu dilatarbelakangi keridhaan dan berkah tuhan, bukan kepentingan duniawi tertentu. aspek perilaku religiusitas, yaitu ketaatan seseorang terhadap ajaran agamanya yang identik dengan ritual ibadah yang wajib maupun sunnah untuk dijalankan oleh penganutnya, seperti shalat fardhu dan sunnah, puasa, membaca Alquran, dan lain sebagainya.

Hidup juga dimaknai sebagai kerja keras dalam budaya Bugis (Reso'). Arti dari Reso adalah sistem dengan nilai kehormatan, yang merupakan representasi dari nilai siri, bahkan dalam adat Bugis. Tidak heran jika budaya Bugis menganut paham Reso' 
temmangingngi nalletei pammase dewata jika seseorang yang sudah cukup umur tetapi tidak mempunyai pekerjaan, malah menjadi beban bagi orang lain (masiri narekko tuo mappale) (usaha yang sungguh-sungguh). Hal inilah yang menjadikan suku Bugis terkenal sebagai salah satu suku pekerja yang ulet di segala bidang industri, termasuk sektor usaha pertanian khususnya di Sulawesi Selatan pada umumnya yang merupakan hub tanaman pangan dan persawahan menjadi salah satu tolok ukur penguasa. dari suku Bugis (Yusuf, 2013).

Reso dalam bahasa Indonesia dimaknai sebagai usaha, nilai kunci bagi pelaksanaan nilai-nilai kejujuran, kecendekiaan, kepatutan dan keteguhan. Nilai-nilai ini berperanan secara bertepat guna dan berdaya guna apabila didukung oleh nilai usaha. Dengan sendirinya nilai usaha inipun tegak di atas landasan nilai-nilai tersebut. Nilai kejujuran yang berperanan di dalam diri To Akkarangeng Datu Soppeng dan La Pagala Nenek Mallomo; nilai kecendekiaan di dalam diri To Suwalle Kajao Laliddong, dan lain-lain; nilai kepatutan dalam diri La Taddampare' Puang ri Maggalatung, dan lain-lain; dan nilai keteguhan di dalam diri beberapa mangkau' (Arumpone). Empat hal menjadi perhatikan pada sikap Reso diantaranya: kejujuran karena menimbulkan kepercayaan; pergaulan, karena akan mengembangkan usaha; keilmuan, karena akan memperbaiki pengelolaan dan ketatalaksanaan; dan modal karena inilah yang ikut menggerakkan usaha (Tim Penyusun, 2008).

Ininnawa merupakan budaya bugis yang berasal dari kata nawa atau nawa-nawa, yang mengacu pada rencana yang masih bersifat relatif, baik atau buruk. Disebut ininnawa jika baik. Makna konsep ini adalah mendorong kita untuk bertindak sesuai dengan akal dan hati nurani, dengan niat yang luhur. Bukankah hati tidak pernah berbohong (Tim Penyusun, 2008). Hal inilah yang seharusnya banyak diimplementasikan dalam proses penyajian laporan keuangan untuk kebaikan para pemangku kepentingan pada entitas.

Jika nawa-nawa itu baik, maka disebut sebagai ininnawa. Jadi ininnawa adalah konsekuensi dari keharmonisan pikiran antara akal dan hati nurani, yang memiliki tujuan mulia untuk mencapai harapan sejati sebelum bertindak. Dari segi definisi keindahan, inninawa adalah bentuk ideal dari kecantikan yang ada dalam pikiran seseorang. Begitulah orang Bugis memandangnya. Sesuatu yang padat, atau "watang", tidak lebih dari sebuah bayangan. Apa yang kita lihat sebenarnya adalah manifestasi dari "inkarnasi" pikiran. Semua jenis seni dianggap sebagai cerminan sejati dari pikiran seniman pada saat penciptaan.

Kapal Pinisi, misalnya. Gagasan tentang Pinisi dianggap lebih indah dari pada Pinisi itu sendiri. Phinisi hanyalah "bayangan" dari konsepsi orang Bugis tentang pembuatan kapal. Orang Bugis percaya bahwa kecantikan adalah konsep yang sederhana. Akibatnya, tidak ada yang namanya keindahan. Sifatnya tidak memiliki batas. Sesuatu yang indah dianggap tak ternilai harganya (tidak bisa dinilai), dan tidak bisa digambarkan.

"Narekko maeloko mpukke seuwwa jama-jamang, Pattepu menni ri Ininnawa-mu," yang dapat dimaknai bahwa jika Anda merencanakan pekerjaan, lakukan terlebih dahulu dan selesaikan dengan niat baik. Itu nasehat nenek moyang orang Bugis. Ini tidak berarti 
bahwa itu menandakan masa depan Tuhan, tetapi itu menyiratkan bahwa untuk melaksanakan rencana atau pekerjaan, itu harus dipikirkan dan didirikan dengan benar di atas ininnawa. "Semua pekerjaan, jika direncanakan dengan benar, akan memberikan hasil yang memenuhi harapan kami." Atau "Masolammua Mapatae, masolappi dua tellu massola-solae," demikian bunyinya.

Penyajian laporan keuangan seharusnya dimaknai sedemikian rupa dan disajikan dengan sungguh-sungguh dengan niat yang baik demi kebaikan entitas dan lainnya. Sehingga tidak ada yang dirugikan berkaitan dengan informasi pada laporan keuangan yang disajikan. Isu penyajian laporan keuangan yang juga menjadi perdebatan adalah terkait masalah transparansi. Meskipun transparansi telah digambarkan sebagai karakteristik yang diinginkan dari laporan keuangan, transparansi tidak didefinisikan dengan baik dalam konteks pelaporan keuangan. Definisi transparansi pelaporan keuangan yang mengekstrapolasi dari cara transparansi digunakan dalam konteks lain. Transparansi pelaporan keuangan adalah sejauh mana laporan keuangan mengungkapkan kondisi ekonomi yang mendasari entitas dengan cara yang mudah dimengerti oleh mereka yang menggunakan laporan keuangan. Definisi ini bertumpu pada dua konsep kunci ekonomi yang mendasari dan mudah dimengerti yang perlu ditangani untuk memperjelas definisi dan implikasinya untuk pelaporan keuangan. Sama halnya dengan konsep yang ditawarkan International Accounting Standards Board (IASB) dan Financial Accounting Standards Board (FASB) mengenai ambiguitas dalam penyajian laporan keuangan yang harus dihilangkan serta mudah dipahami (Barth \& Schipper, 2008).

Transparansi penyajian laporan keuangan dapat pula dikiaskan dalam proses transmisi cahaya dimana suatu barang dapat dilihat dalam berbagai sudut pandang. Makna ini berkonotasi visibilitas dan membawa ke pengertian keterbukaan dan komunikasi, sebagai lawan dari kerahasiaan dan penyembunyian. Agar transparan, laporan keuangan perlu menyertakan informasi tentang kondisi keuangan yang mendasari entitas dan dapat dipahami oleh pengguna. Dengan demikian, perlu memasukkan cukup detail untuk membantu pengguna dalam membuat keputusan, tetapi tidak terlalu detail sehingga sulit bagi pengguna untuk membedakan kondisi keuangan yang mendasari entitas. Selain itu, informasi harus dikomunikasikan dengan cara yang dapat dipahami oleh mereka yang ingin menggunakan informasi tersebut.

Lain daripada itu terdapat pula beberapa kesulitan dengan kriteria tertentu dalam proses pemaknaan informasi dalam laporan keuangan yang diakibatkan oleh kurangnya pengetahuan serta sifat keahlian pengguna laporan keuangan. Apa yang mudah dimengerti dalam informasi laporan keuangan sangat bervariasi sesuai dengan keahlian akuntansi setiap individu, pengetahuan tentang transaksi yang dilaporkan, dan keterampilan analisis laporan keuangan. Laporan keuangan yang transparan bagi pakar akuntansi yang memiliki pengetahuan bisnis dan industri yang substansial mungkin tidak jelas bagi pengguna yang tidak memiliki pengetahuan tersebut. Oleh karena itu seharusnya laporan keuangan difokuskan pada pengguna yang memiliki pengetahuan yang wajar tentang kegiatan bisnis dan ekonomi serta pelaporan keuangan, dan yang mempelajari informasi dengan ketekunan yang wajar dan bahwa informasi yang relevan tidak boleh dikecualikan dari laporan keuangan semata-mata karena mungkin terlalu rumit atau sulit untuk dipahami oleh beberapa pengguna (Hunton et al., 2006). 
Lebih lanjut (Chan et al., 2005) mengemukakan bahwa perusahaan yang diidentifikasi melakukan manajemen laba cenderung memilih pengungkapan yang kurang transparan, sejauh mana format pelaporan yang lebih transparan akan mengurangi kecenderungan manajer untuk terlibat dalam manajemen laba. Lebih lanjut, penggunaan ukuran korelasional dari manajemen laba tidak memungkinkan untuk membedakan antara manajemen laba yang meningkatkan pendapatan dan menurunkan pendapatan, atau menilai keyakinan manajer yang mendasari pilihan manajemen laba mereka.

Nilai spiritual merupakan dasar bagi setiap manusia dalam menjalankan aktivitasnya didunia. Nilai spiritual juga menjadi pedoman bagi setiap manusia yang beragama, misalnya Alquran dan Hadis di agama Islam (Khaldun, 1977). Oleh karena itu penelitian ini mengusulkan nilai spiritual dimasukkan ke dalam unsur penyajian laporan keuangan. Integritas merupakan pribadi yang jujur, memiliki karakter yang kuat, atau dalam Bahasa latin disebut sebagai integer atau sikap yang teguh, mempertahankan prinsip, tidak mau korupsi dan lekat pada nilai moral (Tim Penyusun, 2008). Sehingga apabila dimasukkan kedalam unsur penyajian laporan keuangan akan menguatkan prosesnya untuk menghasilkan informasi yang transparan dan dapat dipertanggungjawabkan. Selanjutnya nilai Reso' dalam budaya bugis dapat dimaknai sebagai usaha yang sungguh-sungguh yang didasarkan kepada keyakinan kepada Allah swt. Sehingga apa yang dikerjakannya merupakan tanggungjawab didunia maupun diakhirat. Dengan adanya nilai Reso' dalam proses penyajian laporan keuangan, diharapkan dapat memberikan transparansi yang sebenarnya pada informasi keuangan yang ada didalam laporan keuangan. Kemudian terdapat pula nilai Ininnawa yang dapat dimaknai sesuatu yang didasarkan pada pertimbangan akal, hati nurani, nilai luhur. Sehingga apa yang dihasilkannya akan memberikan kebaikan dan kemaslahatan. Ininnawa dalam unsur penyajian laporan keuangan juga menjadi sesuatu yang penting untuk dipertimbangkan sebagai dasar agar transparansi informasi laporan keuangan dapat terwujud. Keempat nilai (value) tersebut diusulkan menjadi suatu konsep dalam proses penyajian laporan keuangan yang disebut sebagai SIRI value (Spiritual, Integrity, Reso', dan Ininnawa) yang digambarkan sebagai berikut:

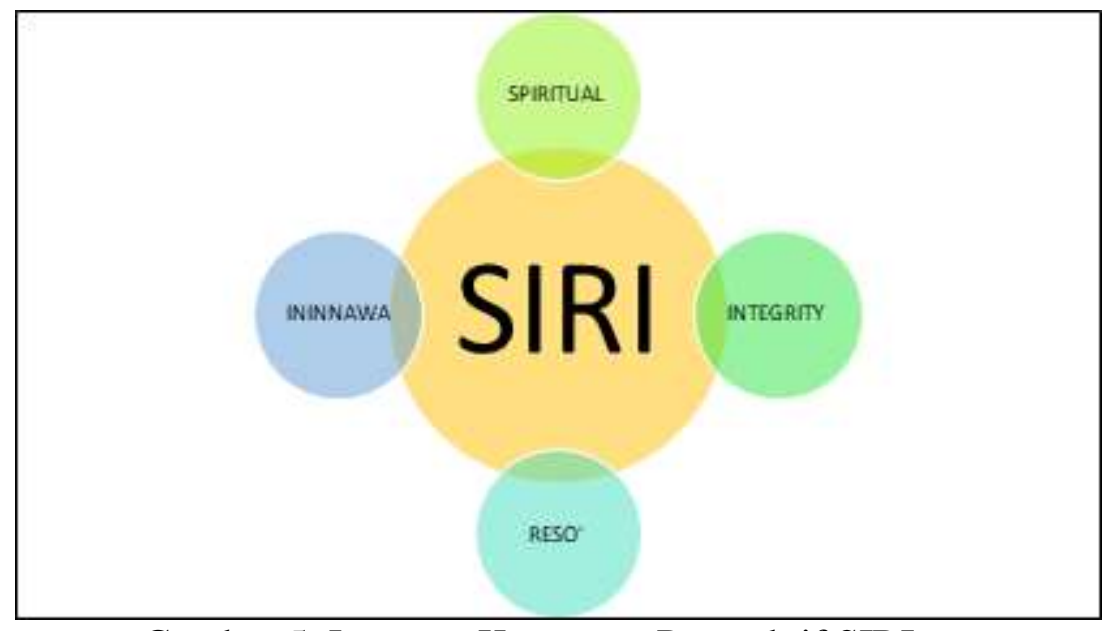

Gambar 5. Laporan Keuangan Perspektif SIRI

Sumber: Diolah sendiri. 


\section{KESIMPULAN}

Isu transparansi telah menjadi suatu permasalahan yang mengakibatkan adanya asimetri informasi dalam proses penyajian laporan keuangan. Diperlukan suatu perspektif baru dalam penyajian laporan keuangan. Oleh karena itu penelitian ini mengusulkan konsep SIRI (Spiritual, Integrity, Reso, dan Ininnawa) sebagai landasan yang dapat meminimalisir terjadinya permasalahan transparansi laporan keuangan.

1. Spiritual, memberikan kesadaran keberagamaan kepada manusia dalam menjalankan aktivitas pekerjaannya, dalam hal ini adalah proses penyajian laporan keuangan.

2. Integrity, merupakan tanggungjawab dalam melaksanakan pekerjaan dengan sungguh-sungguh atau tidak ada yang ditutupi dalam implementasinya. Oleh karena itu nilai Integrity dalam proses penyajian laporan keuangan diharapkan dapat meminimalisir adanya asimetri informasi pada laporan keuangan.

3. Reso, merupakan usaha untuk menyelesaikan sesuatu dengan sungguhsungguh. Hal ini dapat dimaknai bahwa dengan adanya nilai Reso maka penyajian laporan keuangan akan dilakukan dengan sungguh-sungguh untuk kepentingan para penggunanya.

4. Ininnawa berarti menggunakan akal, nilai luhur, dan hati nurani. Proses penyajian laporan keuangan akan disampaikan dengan sebenar-benarnya sehingga pengambilan keputusan dapat tepat sasaran dan mendatangkan manfaat bagi setiap entitas.

\section{REFERENSI}

al-Qaradawi, Y. (2005). Education And Economy in The Sunnah (Issue 2). ScribeDigital. com.

Alam, M. M., Johari, R. J., \& Said, J. (2018). An empirical assessment of employee integrity in the public sector of Malaysia. International Journal of Ethics and Systems.

Barfuss, F. R., \& Rosenberg, D. G. (1981). FASB statement of financial accounting concepts No. 2. The CPA Journal (Pre-1986), 51(000003), 83.

Barth, M. E., \& Landsman, W. R. (2010). How did financial reporting contribute to the financial crisis? European Accounting Review, 19(3), 399-423.

Barth, M. E., \& Schipper, K. (2008). Financial reporting transparency. Journal of Accounting, Auditing \& Finance, 23(2), 173-190.

Beuselinck, C., \& Manigart, S. (2007). Financial reporting quality in private equity backed companies: The impact of ownership concentration. Small Business Economics, 29(3), 261-274.

Bhattacharya, U., Daouk, H., \& Welker, M. (2003). The world price of earnings opacity. The Accounting Review, 78(3), 641-678.

Bogdan, R., \& Taylor, S. J. (1975). Introduction to Qualitative Methods Research, A Phenomenological Approach to Social Sciences. New York: John Willey \& Son.

Boisjoly, R. M. (2017). Personal integrity and accountability. In Engineering Ethics (pp. 397-407). Routledge.

Brown, T. J. (2014). Advantageous comparison and rationalization of earnings management. Journal of Accounting Research, 52(4), 849-876. 
Chan, K. C., Farrell, B. R., \& Lee, P. (2005). Earnings management and returnearnings association of firms reporting material internal control weaknesses under Section 404 of the Sarbanes-Oxley Act. Available at SSRN 744806.

Dechow, P., Ge, W., \& Schrand, C. (2010). Understanding earnings quality: A review of the proxies, their determinants and their consequences. Journal of Accounting and Economics, 50(2-3), 344-401.

Dechow, P. M., Sloan, R. G., \& Sweeney, A. P. (1995). Detecting earnings management. Accounting Review, 193-225.

FASB, F. A. (1980). Statement of financial accounting concepts no. 2: Qualitative characteristics of accounting information. In Financial Accounting Standards Board, of the Financial Accounting Foundation.

Haniati, S., \& Fitriany, F. (2010). Pengaruh Konservatisme Terhadap Asimetri Informasi Dengan Menggunakan Beberapa Model Pengukuran Konservatisme. Di Purwokerto: Seminar Nasional Akuntansi XIII.

Healy, P. M., \& Wahlen, J. M. (1999). A review of the earnings management literature and its implications for standard setting. Accounting Horizons, 13(4), 365-383.

Hunton, J. E., Libby, R., \& Mazza, C. L. (2006). Financial reporting transparency and earnings management (retracted). The Accounting Review, 81(1), 135-157.

Jonas, G. J., \& Blanchet, J. (2000). Assessing quality of financial reporting. Accounting Horizons, 14(3), 353.

Khaldun, A. A. R. I. (1977). Muqaddamah ibn Khaldun. Nafees Academy.

Leuz, C., Nanda, D., \& Wysocki, P. D. (2003). Earnings management and investor protection: an international comparison. Journal of Financial Economics, 69(3), 505-527.

Lin, Z., Jiang, Y., Tang, Q., \& He, X. (2014). Does high-quality financial reporting mitigate the negative impact of global financial crises on firm performance? Evidence from the United Kingdom. Australasian Accounting, Business and Finance Journal, 8(5), 19-46.

Lo, A. K. (2015). Accounting credibility and liquidity constraints: Evidence from reactions of small banks to monetary tightening. The Accounting Review, 90(3), 1079-1113.

Mayangsari, S. (2003). Analisis pengaruh independensi, kualitas audit, serta mekanisme corporate governance terhadap integritas laporan keuangan. Simposium Nasional Akuntansi VI, 16, 17.

Mazereeuw-van der Duijn Schouten, C., Graafland, J., \& Kaptein, M. (2014). Religiosity, CSR attitudes, and CSR behavior: An empirical study of executives' religiosity and CSR. Journal of Business Ethics, 123(3), 437-459.

McDaniel, L., Martin, R. D., \& Maines, L. A. (2002). Evaluating financial reporting quality: The effects of financial expertise vs. financial literacy. The Accounting Review, 77(s-1), 139-167.

Nashori, F. N., Mucharam, R. D., \& Ru'iya, S. (2002). Mengembangkan kreativitas dalam perspektif psikologi Islam. Menara Kudus.

Nugraha, R. (2021). Menggagas Penerapan Kode Etik Akuntan Publik Dalam Budaya Bugis. Jurnal Akuntansi Multiparadigma, 12(2).

Nei, K. S., Foster, J. L., Ness, A. M., \& Nei, D. S. (2018). Rule breakers and attention seekers: Personality predictors of integrity and accountability in leaders. International Journal of Selection and Assessment, 26(1), 17-26. 
Ramalingegowda, S., Wang, C.-S., \& Yu, Y. (2013). The role of financial reporting quality in mitigating the constraining effect of dividend policy on investment decisions. The Accounting Review, 88(3), 1007-1039.

Sari, C., \& Adhariani, D. (2009). Konservatisme perusahaan di Indonesia dan faktorfaktor yang mempengaruhinya. Simposium Nasional Akuntansi XII, 12, 1-26.

Schipper, K. (1989). Earnings management. Accounting Horizons, 3(4), 91.

Sgier, L. (2012). Qualitative data analysis. An Initiat. Gebert Ruf Stift, 19, 19-21.

Tikollah, M. R., Triyuwono, I., \& Ludigdo, U. (2006). Pengaruh kecerdasan intelektual, kecerdasan emosional, dan kecerdasan spiritual terhadap sikap etis mahasiswa akuntansi (Studi pada Perguruan Tinggi Negeri di Kota Makassar Provinsi Sulawesi Selatan). Simposium Nasional Akuntansi, 9, 23-26.

Tim Penyusun, K. (2008). Kamus Besar Bahasa Indonesia. Balai Pustaka: Jakarta.

Van Tendeloo, B., \& Vanstraelen, A. (2005). Earnings management under German GAAP versus IFRS. European Accounting Review, 14(1), 155-180.

Wantah, M. J. (2015). Analisis Penerapan Psak No. 1 Tentang Penyajian Laporan Keuangan Pada Perum Bulog Divre Sulut Dan Gorontalo. Jurnal Berkala Ilmiah Efisiensi, 15(4).

Weygandt, J. J., Kimmel, P. D., \& Kieso, D. E. (2018). Financial Accounting with International Financial Reporting Standards. John Wiley \& Sons.

Yusuf, M. (2013). Relevansi Nilai-Nilai Budaya Bugis dan Pemikiran Ulama Bugis: Studi Tafsir Berbahasa Bugis Karya MUI Sulsel. El-HARAKAH (TERAKREDITASI), 15(2), 199-216. 